\title{
PENGARUH INDEPENDENSI, KOMPETENSI DAN PENGALAMAN KERJA AUDITOR TERHADAP KUALITAS AUDIT
}

\author{
Maria Immaculata Adhisti Prima Dewi ${ }^{1)}$, J. Sabas Setyohadi ${ }^{2)}$ \\ ${ }^{1,2}$ Program Studi Pendidikan Ekonomi, \\ Fakultas Ilmu Pendidikan dan Pengetahuan Sosial, Universitas Indraprasta PGRI \\ Email: maria.adhisti1206@gmail.com
}

Diterima: Februari; Disetujui: Maret; dipublikasikan: 28 April 2019

\begin{abstract}
The quality audit is conducted by an independent and competent auditor. This research is aimed at describing the influence auditor's independence, competence and working experience upon audit quality in the Office of Public Accountant in Jakarta. The method employed in this research surveys with the technique being questionnaire. The population for this research is all auditors working in the Office of Public Accountant in Jakarta. The technique used to make sampling in this research is nonrandom sampling/nonprobability sampling with 180 samples. The data is analyzed by using the Multiple Regression Model. The result of research indicates that auditor's independence, competence, and working experience have a positive and significant impact on audit quality. In addition, the result shows that there is a low average (mean) of correlation between independence, competence, and working experience and audit quality in a partial way.
\end{abstract}

Keywords: independence, competence, working experience, audit quality

\begin{abstract}
ABSTRAK
Kualitas audit ditentukan oleh auditor yang independen dan kompeten. Penelitian ini bertujuan untuk mengetahui dan menganalisis pengaruh independensi auditor, kompetensi, dan pengalaman kerja terhadap kualitas audit pada Kantor Akuntan Publik (KAP) di wilayah DKI Jakarta. Penelitian ini dilakukan dengan survey melalui teknik penyebaran angket . Populasi dalam penelitian ini adalah seluruh auditor yang bekerja pada kantor akuntan public di wilayah DKI Jakarta. Metode penarikan sampel yaitu dengan teknik non probability sampling, diperoleh jumlah sampel sebanyak 180 orang. Teknik analisis data menggunakan analisis regresi linear berganda.Hasil penelitian menunjukkan terdapat pengaruh yang positif dan signifikan antara independensi auditor, kompetensi, dan pengalaman kerja terhadap kualitas audit. Selain itu, hasil penelitian menunjukkan adanya hubungan yang relatif lemah antara independensi, kompetensi, dan pengalaman kerja dengan kualitas audit pada uji secara parsial.
\end{abstract}

Kata Kunci: Independensi, Kompetensi, Pengalaman Kerja, dan Kualitas Audit 


\section{PENDAHULUAN}

Seorang yang berprofesi sebagai akuntan publik memiliki suatu kepercayaan dari masyarakat, dimana masyarakat mengaharapkan penilaian yang bebas dan tidak memihak terhadap informasi yang disajikan oleh manajemen perusahaan dalam laporan keuangan (Mulyadi, 2002). Akuntan Publik bertugas untuk melakukan audit terhadap laporan keuangan dan memberikan suatu pendapat apakah laporan keuangan tersebut menyajikan secara wajar, dalam semua hal yang material, posisi keuangan, dan hasil entitas sesuai dengan Standard Akuntansi Keuangan (SAK) atau Prinsip Akuntansi Berterima Umum (PABU).

Namun, akhir-akhir ini kredibilitas akuntan publik mulai diragukan oleh masyarakat luas, hal tersebut disebabkan oleh munculnya berbagai kasus audit yang terjadi baik di dalam maupun di luar Indonesia yang menyebabkan krisis kepercayaan terhadap profesi akuntan publik, seperti kasus yang menjadi sorotan dunia, yaitu kasus Enron, serta kasus Bank Lippo yang melanda di Indonesia. Adanya berbagai kasus kegagalan audit, seperti contoh di atas, membuat persepsi masyarakat khususnya para pemakai laporan keuangan meragukan dan mempertanyakan kredibilitas auditor sebagai pelaku pemeriksa keuangan. Peranan auditor untuk meningkatkan kualitas auditnya sangat diperlukan untuk mendapatkan kembali kepercayaan yang diberikan oleh masyarakat. Para pengguna jasa akuntan publik ini tentunya sangat mengharapkan agar para auditor dapat memberikan opini yang tepat dan tercapainya laporan keuangan auditan yang berkualitas, karena kualitas audit yang tinggi akan menghasilkan laporan keuangan yang dapat dipercaya sebagai dasar pengambilan keputusan bagi para penggunanya. Kepercayaan yang besar dari para pemakai laporan keuangan auditan dan jasa lainnya yang diberikan, mengharuskan akuntan publik memperhatikan kualitas audit yang dihasilkan.

Kualitas Audit ditentukan oleh dua hal, yaitu kompetensi dan Independensi (Christiawan, 2002). Kualitas audit yang baik pada prinsipnya dapat dicapai jika auditor menerapkan standarstandar dan prinsip-prinsip audit, bersikap bebas tanpa memihak (Independen), patuh kepada hukum serta mentaati kode etik profesi. Independensi menurut Mulyadi (2002) dapat diartikan sebagai sikap mental yang bebas dari pengaruh, tidak dikendalikan oleh pihak lain, tidak tergantung pada orang lain. Independensi juga berati adanya kejujuran dalam auditor dalam mempertimbangkan fakta dan adanya pertimbangan yang objektif tidak memihak dalam diri auditor dalam merumuskan dan menyatakan pendapatmya. Independensi berarti auditor tidak mudah dipengaruhi, karena dia melaksanakan pekerjaan untuk kepentingan umum. Auditor tidak dibenarkan memihak kepentingan siapapun. Auditor berkewajiban untuk jujur tidak hanya kepada pemerintah, namun juga kepada lembaga perwakilan dan pihak lain yang meletakan kepercayaan atas pekerjaan auditor.

Faktor lainnya yang tidak dapat dipisahkan dari independensi adalah kompetensi. Kompetensi dan independensi adalah sepasang kualitas yang harus dimiliki oleh auditor. Kompetensi berhubungan dengan keahlian, pengetahuan, dan pengalaman sehingga auditor yang kompeten adalah auditor yang memiliki pengetahuan, pelatihan, keterampilan dan pengalaman yang memadai agar bisa berhasil menyelesaikan pekerjaan auditnya. Zu'amah (2009) menyatakan bahwa kompetensi merupakan keahlian profesional auditor yang didapatkan melalui pendidikan formal, ujian profesional maupun keikutsertaan dalam pelatihan, seminar, simposium.

Penelitian ini mengacu kepada penelitian yang telah dilakukan oleh Alim dkk. (2007), yakni pengujian pengaruh kompetensi dan independensi terhadap kualitas audit dengan etika auditor sebagai variabel moderasi. Perbedaan penelitian ini dengan penelitian sebelumnya, adalah bahwa adanya penambahan variabel pengalaman kerja sebagai faktor dari pengaruh kualitas audit dan penghapusan variabel etika auditor sebagai variabel moderasi, selain itu sampel yang digunakan dalam penelitian sebelumnya menggunakan auditor yang bekerja di 
KAP Jawa Timur sedangkan penelitian ini akan mengunakan Kantor Akuntan Publik (KAP) anggota The Big Four di Jakarta dan KAP Non-The Big Four. Objek penelitian ini adalah auditor yang bekerja di Kantor Akuntan Publik (KAP) di Jakarta.

Penelitian ini menambahkan pengalaman kerja sebagai faktor yang mempengaruhi kualitas audit dikarenakan sesuai dengan standar umum dalam Standar Profesional Akuntan Publik bahwa auditor disyaratkan memiliki pengalaman kerja yang cukup dalam profesi yang ditekuninya, serta dituntut untuk memenuhi kualifikasi teknis dan berpengalaman dalam industri-industri yang mereka audit (Arens dkk., 2008). Pengalaman juga memberikan dampak pada setiap keputusan yang diambil merupakan keputusan yang tepat. Hal tersebut mengindikasikan bahwa semakin lama masa kerja yang dimiliki auditor maka kualitas audit yang dihasilkan semakin baik.

Teori keagenan (Agency Theory) menjelaskan tentang dua pelaku ekonomi yang saling bertentangan, yaitu principal dan agen. Hubungan keagenan merupakan kontrak antara pemilik sumber daya ekonomis (principal) memerintah orang lain (agent) untuk melakukan suatu jasa atas nama principal serta member wewenang kepada agen membuat keputusan yang terbaik bagi principal (Ichsan, 2013). Menurut Meisser, et al., (2006:7) hubungan keagenan ini mengakibatkan dua permasalahan, yaitu terjadinya informasi asimetris (information asymmetry) dan terjadinya konflik kepentingan (conflict of interest). Fungsi audit yang merupakan bagian dari praktek corporate governance, tidak terlepas dari teori keagenan.

Auditor harus memiliki sikap independensi, yang merupakan sikap tidak memihak kepada kepentingan siapapun dalam melakukan pemeriksaan laporan keuangan yang dibuat oleh pihak manajemen. Auditor mempunyai kewajiban untuk bersikap jujur tidak saja kepada pihak manajemen, tetapi juga terhadap pihak ketiga sebagai pemakai laporan keuangan, seperti kreditor, pemilik maupun calon pemilik (Kasidi, 2007).

Kompetensi berhubung dengan keahlian, pengetahuan, dan pengalaman sehingga auditor yang kompeten adalah auditor auditor yang memiliki pengetahuan, pelatihan, keterampilan, dan pengalaman yang memadai agar bisa berhasil menyelesaikan pekerjaan auditnya (Erna dan Febrianto, 2010). Kompetensi menurut Hutapea dan Thoha (2008:28) mengungkapkan bahwa ada tiga komponen utama pembentukan kompetensi, yaitu pengetahuan yang dimiliki seseorang, kemampuan, dan prilaku individu. Dalam penelitian A. Nurfarhana, A. Abdillah, H. Prasetyono. (2017) menyatakan bahwa komponen pengetahuan, kemampuan, dan prilaku berkaitan erat dengan disiplin kerja. Hal ini menunjukkan bahwa kompetensi hampir memiliki indikator yang sama dengan disiplin, atau dengan kinerja.

Knoers dan Haditono (1999) mengatakan bahwa pengalaman kerja merupakan suatu proses pembelajaran dan penambahan perkembangan potensi bertingkah laku baik dari pendidikan formal maupun non formal atau bisa juga diartikan sebagai suatu proses yang membawa seseorang kepada suatu pola tingkah laku yang lebih tinggi. Dalam menjalankan tugasnya, auditor harus memenuhi kualifikasi dan pengalaman dalam berbagai industri tempat klien audit berkecimpung.

Pengalaman kerja dipandang sebagai faktor penting dalam memprediksi dan menilai kinerja auditor dalam melakukan pemeriksaan. Pengalaman yang dimiliki auditor dalam melakukan audit dapat dijadikan pertimbangan auditor berkualitas (Widhiati, 2005). Auditor yang lebih berpengalaman akan lebih cepat tanggap dalam mendeteksi kekeliruan yang terjadi.

Bertambahnya pengalaman kerja auditor juga akan meingkatkan ketelitian dalam melakukan pemeriksaan. Pemeriksaan yang dilakukan dengan tingkat ketelitian yang tinggi akan menghasilkan laporan audit yang berkualitas. 


\section{METODE}

Penelitian ini merupakan penelitian asosiatif kausal, bertujuan untuk meneliti jenis masalah berupa pengaruh antara dua/lebih variabel dengan mengidentifikasikan fakta atau peristiwa tersebut sebagai variabel yang dipengaruhi (variabel dependen) serta melakukan penyelidikan terhadap variabel yang mempengaruhi (variabel independen). Sehingga penelitian ini merupakan studi empiris berbentuk kausalitas yang bertujuan untuk mengetahui pengaruh independensi, kompetensi, dan pengalaman kerja auditor terhadap kualitas audit yang dihasilkan oleh auditor yang bekerja di KAP wilayah DKI Jakarta.

Populasi yang digunakan dalam penelitian ini adalah seluruh auditor yang bekerja pada Kantor Akuntan Publik (KAP) di wilayah DKI Jakarta. Alasan pertimbangan pemilihan lokasi di wilayah DKI Jakarta, dikarenakan wilayah ini sudah mewakili kota-kota besar di pulau Jawa, sedangkan jumlah sampel yang diambil sebanyak 180 auditor untuk dijadikan sampel penelitian. Dasar penulis mengambil sampel sebanyak 180 auditor tersebut, dikarenakan sebagian besar uji statistik selalu menyertakan rekomendasi ukuran sampel.

Dalam penelitian ini, teknik pengambilan sample yang digunakan adalah nonrandom sampling/nonprobability sampling, yaitu setiap elemen populasi tidak mempunyai kesempatan yang sama untuk terpilih sebagai sampel. Penelitian ini menggunakan sampel berdasarkan kemudahan (convenience sampling). Para peneliti memiliki kebebasan untuk memilih siapa saja yang mereka temui, jadi mereka menyebutnya mudah (Cooper dan Emory, 1997:244). Alasan digunakannya metode ini adalah penulis tidak mengetahui dengan pasti berapa jumlah auditor yang bekerja pada KAP di wilayah DKI

Teknik pengumpulan data yang digunakan, yaitu dengan menggunakan teknik survey berupa penyebaran angket (kuesioner) kepada respondennya. Responden yang dimaksud dalam penelitan ini adalah para auditor yang bekerja di KAP wilayah DKI Jakarta. Kriteria responden yang dipilih adalah yang telah bekerja minimal 1 tahun sampai dengan lebih dari 5 tahun auditor bekerja di lapangan, dari posisi junior auditor hingga partner.

Audit yang berkualitas adalah audit yang dilaksanakan oleh orang-orang yang kompeten dan orang yang independen. De Angelo (1981) mengungkapkan paling tepat untuk mendefinisikan bahwa kualitas audit juga tidak hanya bisa didefinisikan sebagai kompetensi tanpa mengikutkan independensi, karena kompetensi dan independensi harus hadir bersamaan agar audit bisa berkualitas. Asthon (1991) dalam Mayangsari (2003) menunjukan bahwa dalam literatur psikologi, pengetahuan spesifik dan lama pengalaman bekerja sebagai faktor penting untuk meningkatkan kompetensi.Maka alur penelitian ini dapat digambarkan sebagai berikut :

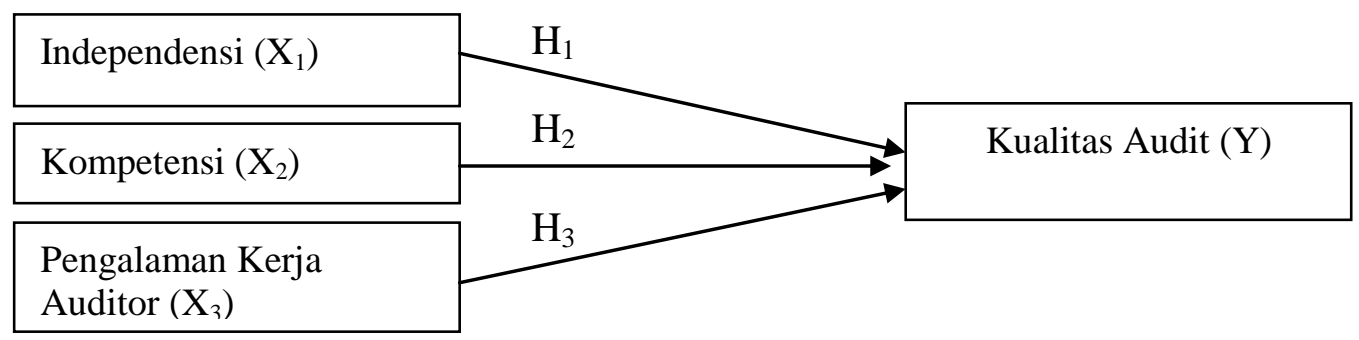

Gambar 1. Model Rerangka Konseptual

Dari rerangka konseptual di atas, penulis dapat menarik hipotesis sebagai berikut:

H1 : Independensi auditor berpengaruh positif terhadap kualitas audit.

H2 : Kompetensi auditor berpengaruh positif terhadap kualitas audit.

H3 : Pengalaman kerja auditor berpengaruh positif terhadap kualitas audit. 
Dalam penelitian ini definisi operasional variabel akan menjelaskan pada variabelvariabel berikut ini : (1)Variabel Independensi $\left(X_{1}\right)$, yang diukur melalui tiga dimensi yaitu : hubungan dengan klien, independensi pelaksanaan pekerjaan dan independensi laporan; (2) Variabel kompetensi $\left(\mathrm{X}_{2}\right)$ yang diukur melalui tiga dimensi yaitu mutu personal, pengetahuan umum dan keahlian khusus; (3) Variabel Pengalaman Kerja Auditor $\left(\mathrm{X}_{3}\right)$ yang diukur melalui dua dimensi yaitu lamanya bekerja seorang auditor dan banyaknya tugas pemeriksaan yang diberikan; (4) serta Variabel Kualitas Audit (Y) yang diukur melalui dimensi kesesuaian pemeriksaan dengan standar audit dan kualitas laporan hasil audit.

Tahap-tahap pengolahan data dalam penelitian ini dilakukan dengan perhitungan profill responden, statistik deskriptif, uji kualitas data, dan uji asumsi klasik. Untuk menguji hipotesis dalam penelitian ini digunakan metode statistik regresi berganda (Multiple Regression) yang bertujuan bertujuan untuk memprediksi berapa besar kekuatan pengaruh variabel independen terhadap variabel dependen. Hubungan antara variabelnya digambarkan dalam persamaan berikut :

$$
\begin{aligned}
& \mathrm{KUA}=\mathbf{a}+\mathrm{b}_{1} \mathrm{INDP}+\mathrm{b}_{2} \mathrm{KOMP}+\mathrm{b}_{3} \mathrm{PKJ}+\mathrm{e} \\
& \text { KUA = Kualitas audit } \\
& \text { a } \quad=\text { Konstanta } \\
& \text { b1,b2,b3 = koefisien regresi } \\
& \text { INDP }=\text { Independensi } \\
& \text { KOMP }=\text { Kompetensi } \\
& \text { PKJ = Pengalaman Kerja Auditor } \\
& \mathrm{e} \quad=\text { error (variabel lainnya yang tidak diuji) }
\end{aligned}
$$

\section{HASIL DAN PEMBAHASAN}

Penelitian ini dilaksanakan pada Kantor Akuntan Publik di wilayah DKI Jakarta. Responden dari penelitian ini adalah auditor yang bekerja di kantor akuntan publik wilayah DKI Jakarta yang terdaftar oleh Institut Akuntan Publik Indonesia (IAPI). Dari 180 kuesioner atau sebesar $100 \%$ yang disebarkan ternyata jumlah kuesioner yang kembali hanya sebanyak 148 kuesioner atau sebesar $82,22 \%$, dan dari jumlah tersebut responden yang menjawab dengan benar dan dapat diolah hanya sejumlah 137 kuesioner atau sebesar 76,11\%.

Deskripsi data disampaikan sebagai penjelasan data yang diambil dari lampiran deskripsi statistik data. Hal ini dilakukan agar penelitian ini memberikan gambaran yang jelas tentang data statistik yang dipergunakan serta diperlukan dalam pembahasan data.

Berdasarkan analisis untuk masing-masing item pertanyaan dari setiap variabel dinyatakan valid. Pengujian signifikansi dilakukan dengan membandingkan nilai r-hitung dengan $r$-tabel untuk tingkat kebebasan $(\mathrm{df} /$ degree of freedom $)=\mathrm{n}-\mathrm{k}$, dalam hal ini $\mathrm{n}$ adalah sampel. Pada penelitian ini, jumlah sampel $(n)=137$ responden Dan besarnya df dapat dihitung dengan $\mathrm{df}=137-2=135$, dengan tingkat alpha $(\alpha)=5 \%$ atau 0,05 . 
Dari perhitungan dapat dilihat bahwa seluruh indikator penilaian dari konstruk independensi, kompetensi dan pengalaman kerja menunjukkan nilai validitas yang baik. Hal tersebut dapat dilihat dari nilai r-hitung yang dimiliki lebih besar dari r-tabel (lampiran uji validitas). Jadi, semua pernyataan dari setiap variabel dinyatakan valid.

Berdasarkan analisis untuk masing-masing variabel independen menunjukkan bahwa semua variabel mempunyai nilai Cronbach Alpha $(\alpha)>0,70$ (lampiran uji reliabilitas). Dengan demikian, item-item pernyataan seluruhnya reliabel atau handal dalam melakukan fungsinya sebagai alat ukur.

Uji Normalitas data dimaksudkan untuk melihat apakah dalam model regresi variabel terikat dan variabel bebas keduanya mempunyai distribusi normal atau tidak. Pengujian normalitas data dalam penelitian ini dengan menggunakan analisis dari kurva Normal P-P plot maupun pada grafik Histogram yang ditunjukkan pada gambar berikut ini.

Berdasarkan hasil analisis dan dengan melihat tampilan grafik histogram maupun kurva penyebaran normal plot (lampiran uji normalitas) dapat disimpulkan bahwa grafik histogram memberikan pola distribusi yang tingkat kemencengan (skewness) nya mendekati normal, sedangkan pada grafik Normal P-P Plot terlihat titik-titk menyebar tidak terlalu jauh disekitar garis diagonal. Pada prinsipnya normalitas data ditunjukkan dengan melihat penyebaran data (titik) pada sumbu diagonal atau dengan melihat histogram dari residualnya.

Pengujian multikolinieritas akan dilakukan dengan menilai pada tolerance serta nilai variance inflation factor (VIF), dengan ketentuan menunjukkan adanya Multikolinieritas jika nilai tolerance $\leq 0,10$ atau sama dengan nilai VIF $\geq 10$. Berdasarkan pengujian SPSS versi 19.00 untuk multikolinieritas seperti pada penelitian ini terlihat bahwa nilai tolerance dari semua variabel $\leq 0,10$ atau VIF $\geq 10$, hal ini bisa diartikan bahwa secara keseluruhan variabel tidak menunjukkan adanya multikolinieritas

Heteroskedastisitas dapat dideteksi dengan melihat grafik scatterplots of residual tidak membentuk pola tertentu (bergelombang, melebar kemudian menyempit, pola linier atau kuadratis). Terlihat dalam gambar scatterplots chart di penelitian ini (lampiran uji heterokedastisitas) nilai yang terdapat pada Scatterplot tersebut menunjukkan pada angka disekitar -2 dan +2 dan tidak membentuk pola tertentu, maka dalam regresi asumsi tidak terjadi heteroskedastisitas dapat dipenuhi.

Model regresi berganda dalam penelitian ini adalah untuk menguji pengaruh variabel independen Independensi $\left(\mathrm{X}_{1}\right)$, Kompetensi $\left(\mathrm{X}_{2}\right)$, dan Pengalaman Kerja Auditori $\left(\mathrm{X}_{3}\right)$ terhadap variabel dependen kualitas audit (Y). Berikut ini adalah uraian hasil pengujian regresi berganda dan output table pengujian dengan menggunakan bantuan program SPSS versi 19. Nilai-nilai hasil pengolahan dengan menggunakan SPSS versi 19 yang dapat dilihat dalam lampiran dapat dikatan bahwa independensi, kompetensi dan pengalaman kerja auditor berpengaruh signifikan terhadap kualitas audit. Hasil pengujian dari setiap hipotesis membuktikan nilai t- tabel sebesar 1,977 yang memiliki nilai lebih kecil dibandingkan dengan masing-masing t-hitung tiap variabel independennya yakni, t-hitung $\left(X_{1}\right)=3,364$; t-hitung $\left(X_{2}\right)=3,249$; t-hitung $\left(X_{3}\right)=3,986$ yang lebih besar daripada t-tabel. Hasil pengujian ini menginterpretasikan bahwa variabel independensi auditor berpengaruh positif dan signifikan terhadap kualitas audit pada taraf signifikansi 5\% atau dengan kata lain masing-masing hipotesis $\mathrm{H} 1, \mathrm{H} 2$ dan $\mathrm{H} 3$ diterima. 
Uji F yang pada dasarnya menunjukkan apakah semua variabel independen atau bebas yang dimasukkan dalam model mempunyai pengaruh secara bersama-sama terhadap variabel dependen atau terikat. Dari pengujian tersebut diperoleh $F$ hitung sebesar 16,538 dengan probabilitas 0,000. Karena probabilitas jauh lebih kecil dari nilai signifikan 0,05, maka model regresi dapat digunakan untuk memprediksi kualitas audit atau dapat dikatakan bahwa independensi, kompetensi dan pengalaman kerja auditor secara simultan berpengaruh terhadap kualitas audit.

Selain itu, dari analisis diperoleh dengan nilai koefisien korelasi $\mathrm{R}=0,521$. Sedangkan pengujian terhadap koefisien determinasi (Adjusted $R$ Square) pada intinya mengukur seberapa jauh kemampuan variabel independen dalam menerangkan variasi variabel dependen. yang besar nilai Adjusted $R$ Square adalah 0,255. Nilai ini menunjukan bahwa 25,5\% variasi kualitas audit dapat dijelaskan oleh variasi dari ketiga variabel independen yaitu independensi, kompetensi dan pengalaman kerja auditor. Sedangkan sisanya 74,5\% dijelaskan oleh sebab lain diluar model.

Penelitian ini menguji pengaruh independensi, kompetensi dan pengalaman kerja auditor terhadap kualitas audit. secara keseluruhan, hasil pengujian hipotesis dengan menggunakan regresi berganda dapat dilihat pada uraian berikut ini : Hipotesis pertama menyatakan bahwa independensi berpengaruh positif terhadap kualitas audit. Hal ini berarti semakin seorang auditor memiliki sikap independensi dalam melakukan audit maka semakin besar nilai tingkat kualitas auditnya. Ssuatu pelaporan yang berkualitas merupakan bentuk pelaporan yang independen, dimana pelaporan tidak terpengaruh oleh pihak lain, tidak menimbulkan multitafsir dan mengungkapkan sesuai dengan fakta. Pelaporan yang independen hanya dapat dilakukan oleh auditor yang berpengalaman dan memiliki keahlian. Hasil ini dipertegas melalui gambaran responden yang menunjukkan jumlah responden yang berkedudukan sebagai seorang supervisor, manager dan partner tidak memiliki jumlah yang banyak atau dibawah 20\%. Dengan demikian dapat disimpulkan ketiga level jabatan tersebut merupakan pihak yang dianggap semakin tinggi kedudukannya, maka semakin besar sikap independensi yang diberikan dalam menghasilkan laporan audit yang berkualitas.

Hipotesis kedua menyatakan bahwa kompetensi berpengaruh positif terhadap kualitas audit. Hal ini berarti semakin tinggi kompetensi seorang auditor maka akan semakin tinggi pula kualitas audit yang dihasilkan. Hasil tersebut dapat dipahami bahwa kualitas audit dapat dicapai jika auditor memiliki kompetensi yang baik. Hal ini dipertegas dengan tingkat pendidikan yang ditempuh oleh seorang auditor yang digambarkan dalam demografi responden menunjukan bahwa lulusan sarjana S1 dan S2 memiliki jumlah lebih dari 50\%. Berdasarkan gambaran jumlah responden tersebut, dapat disimpulkan bahwa kompetensi dapat diukur dari seberapa tinggi pendidikan seorang auditor, karena dengan demikian auditor akan mempunyai semakin banyak pengetahuan mengenai bidang yang digelutinya sehingga dapat mengetahui berbagai masalah secara lebih mendalam. Dengan demikian, auditor sebagai ujung tombak pelaksana tugas audit memang harus senantiasa meningkatkan pengetahuan yang telah dimiliki agar penerapan pengetahuan dapat maksimal dalam praktiknya.

Hipotesis ketiga untuk variabel pengalaman kerja auditor yang diproksikan dalam dua dimensi yaitu lama bekerja dan banyaknya tugas pemeriksaan menyatakan bahwa pengalaman kerja auditor berpengaruh positif terhadap kualitas audit. Seorang auditor yang memiliki 
pengalaman kerja yang banyak, maka akan membuat apa yang dikerjakan dan hasil dari yang ia periksa semakin berkualitas atau memiliki kualitas audit yang tinggi pula. Hal ini menunjukan bahwa semakin lama menjadi seorang auditor dan semakin banyak tugas pemeriksaan yang diberikan akan semakin mengerti bagaimana menghadapi entitas atau objek pemeriksaan dalam memperoleh data dan informasi yang relevan yang dibutuhkan untuk membuat keputusan serta dapat mendeteksi kesalahan dan mencari penyebab munculnya kesalahan sehingga dapat memberikan rekomendasi yang tepat bagi entitas atau objek yang diperiksa. Hasil tersebut dipertegas dengan hasil demografi responden yang menyatakan bahwa jumlah responden yang bekerja diatas dua tahun memiliki jumlah $75,19 \%$, hal itu berarti bahwa semakin lamanya seorang auditor bekerja maka kualitas hasil pemeriksaan yang dihasilkan akan semakin meningkat. Selain itu jabatan yang banyak diduduki oleh responden dalam penelitian ini yaitu senior auditor sebesar 43,07\% menunjukan bahwa pengalaman berpengaruh menentukan posisi jabatan seorang auditor untuk dapat meriview terhadap hasil pekerjaan auditor juniornya.

\section{SIMPULAN DAN SARAN}

\section{Simpulan}

Penelitian ini bertujuan untuk mendapatkan bukti empiris atas pengaruh independensi, kompetensi dan pengalaman kerja auditor terhadap kualitas audit yang dilakukan pada seluruh auditor KAP di wilayah DKI Jakarta. Berdasarkan hasil penelitian maka dapat diambil kesimpulan bahwa independensi, kompetendi dan pengalaman kerja memiliki pengaruh positif signifikan terhadap kualitas audit.

Berdasarkan uraian yang sudah dijelaskan di bab sebelumnya, berikut disampaikan beberapa implikasi dari penelitian ini :

1. Penelitian ini berimplikasi pada pengalaman audit dengan tingkat kualitas audit yang dihasilkan sangat menentukan seorang auditor dalam mentukan sikap dan opini terhadap klien.

2. Selain itu, implikasi yang diberikan dalam penelitian ini adalah terlihatnya pengaruh tingkat kualitas audit yang digambarkan dari variabel tingkat independensi, kompetensi dan pengalaman kerja auditor, dimana variabel tersebut mempunyai dampak yang cukup besar seorang auditor dalam pengambilan keputusan.

3. Secara teoretis, hasil penelitian ini diharapkan dapat mendorong dan memberikan motivasi bagi penelitian selanjutnya agar dapat lebih spesifik meneliti hal-hal apa saja yang dapat mempengaruhi tingkat kualitas audit.

\section{Saran}

Berdasarkan hasil penelitian yang telah dilakukan maka diajukan saran, antara lain yaitu:

1. Untuk KAP di kota Jakarta, agar meningkatkan sikap independensi dalam melakukan penugasan dalam pemeriksaan audit. Auditor harus dapat mempertahankan sikap mental independen karena opini yang dikeluarkannya bertujuan untuk menambah kredibilitas laporan keuangan yang disajikan manajemen, sehingga jika auditor tidak independen maka kualitas audit yang dihasilkan tidak baik. Dari segi kompetensi, disarankan agar para auditor 
diberikan pelatihan untuk meambah keahliannya dalam mengaudit secara cepat, tepat dan cermat, sedangkan dari segi pengalaman kerja disarankan untuk para senior dapat memberikan supervisi secara langsung agar dapat membentuk junior-junior auditor yang lebih ahli dalama melakukan audit di berbagai macam perusahaan.

2. Untuk peneliti selanjutnya, agar dapat memperluas lingkup penelitian, mengembangkan sendiri instrumen pengukuran variabel penelitian untuk penelitian selanjutnya, menghindari adanya kelemahan yang diakibatkan oleh ketidaksesuaian penerjemahan instrumen pengukuran variabel penelitian .

\section{DAFTAR RUJUKAN}

Nurfarhana, A., Abdillah, A, Prasetyono, H. (2017). Faktor yang berpengaruh terhadap disiplin kerja guru SMKN 1 Depok dan SMKS YAPAN Indonesia. Research and development journal of education. 4 (1), 2017.

Alim, M.N., Hapsari, T., \& Purwati, L. (2007). "Pengaruh Kompetensi dan Independensi Terhadap Kualitas Audit dengan Etika Auditor Sebagai Variabel Moderasi”, Simposium Nasional Akuntansi X, Makasar.

Arens, Alvin A. James L. Loebbecke. (2008). Auditing Pendekatan Terpadu, Terjemahan oleh Amir Abadi Yusuf, Buku Dua, Edisi Indonesia, Salemba Empat, Jakarta.

Christiawan, Y.J.(2002).Kompetensi dan Independensi Akuntan Publik: Refleksi Hasil Penelitian Empiris. Jurnal Akuntansi dan Keuangan. 4.(2).hh.79-92.

Cooper, D,R., \& Emory, W, C.(1997). Metode Penelitian Bisnis. Erlangga, Jakarta.

Erna,W., \& Febrianto, R., (2010). Pengukuran Kualitas Audit: Sebuah Esai, Jurnal.

Ghozali, Imam. (2011). Aplikasi Analisis Multivariate dengan Program SPSS. Edisi 3, Badan Penerbit Universitas Diponegoro, Semarang.

Hutapea, P., \& Thoha, N. (2008). Kompetensi Plus: Teori, Desain, Desain, Kasus dan Penerapan untuk HR dan Organisasi yang Dinamis. Jakarta: Grammedia Pustaka Utama.

Ichsan. (2013). Teori Keagenan (Agency Theory).diakses dari https://bungrandhy.wordpress.com/2013/01/12/teori-keagenan.

Jensen \& Meckling. (1976). The Theory of The Firm : Manajerial Behaviour, Agency Cost, and Ownership Structure. Journal of Financial and Economics, $3: 305-360$.

Kasidi. (2007). Faktor-Faktor yang Mempengaruhi Independensi Auditor (Persepsi Manajer Keuangan Perusahaan Manufaktur Di Jawa Tengah). Semarang. Tesis Maksi : Universitas Diponegoro

Knoers dan Haditono. (1999). Psikologi Perkembangan : Pengantar dalam Berbagai Bagian. Cetakan ke-12, Yogyakarta : Universitas Gajah Mada

Mayangsari, S. (2003). Pengaruh Keahlian Audit dan Independensi Terhadap Pendapat Audit : Sebuah Kuasieksperimen. Jurnal Riset Akuntansi Indonesia. 6 (1). hh 1-22

Messier et.al. (2006). Auditing and Assurance Services. Terjemahan Nuri Hinduan. Jakarta: Salemba Empat

Widhiati, M. (2005). Pengaruh Independensi dan Pengalaman Kerja Internal Auditor terhadap Efektivitas Penerapan Struktur Pengendalian Intern pada Hotel Berbintang di Kabupaten Badung dan Kota Madya Denpasar. Skripsi. Fakultas Ekonomi Universitas Udayana. Bali.

Zu'amah ,S. (2010). Independensi dan Kompetensi Auditor Pada Opini Audit (Studi BPK Jateng). Jurnal Dinamika Akuntansi, 1, (2), pp. 145-154 